\title{
FIRE REGIMES AT THE TRANSITION BETWEEN MIXEDWOOD AND CONIFEROUS BOREAL FOREST IN NORTHWESTERN QUEBEC
}

\author{
Yves Bergeron, ${ }^{1,5}$ Sylvie Gauthier, ${ }^{1,2}$ Mike Flannigan, ${ }^{1,3}$ and Victor Kafka ${ }^{1,4}$ \\ ${ }^{1}$ Groupe de recherche en écologie forestière interuniversitaire (GREFi), Université du Québec à Montréal, P.O. Box 8888, \\ Succursale Centre-Ville, Montréal, Québec, Canada H3C 3P8 \\ ${ }^{2}$ Natural Resources Canada, Canadian Forest Service, Laurentian Forestry Centre, P.O. Box 3800, 1055 du P.E.P.S, \\ Sainte-Foy, Québec, Canada G1V 4 C7 \\ ${ }^{3}$ Natural Resources Canada, Canadian Forest Service, Great Lakes Forestry Centre, 1219 Queen Street East, \\ Sault Ste-Marie, Ontario, Canada P6A 2 E5 \\ ${ }^{4}$ Canadian Heritage, Parks Canada Agency, 25 Eddy, Jules Léger Building, 4th floor, Hull, Québec, Canada K1A 0M5
}

Abstract. Fire history was reconstructed for an area of $15000 \mathrm{~km}^{2}$ located in the transition zone between the mixed and coniferous forests in Quebec's southern boreal forest. We used aerial photographs, archives, and dendroecological data (315 sites) to reconstruct a stand initiation map for the area. The cumulative distribution of burnt area in relation to time since fire suggests that the fire frequency has decreased drastically since the end of the Little Ice Age (about 1850) in the entire region. However, a large part of the area was burned between 1910 and 1920 during intensive colonization and when the climate was very conducive to fire. For the period 1920-1945, large fires have mainly been concentrated in the more populated southern area, while few fires have been observed in the virgin coniferous forest in the north. Despite slight differences between the south and the north, fire cycles or the average number of years since fire are not significantly different. Since 1945 , there have been far more fires in the south, but the mean fire size was smaller than in the north. These results suggest that the transition between the mixed and coniferous forests observed in the southern boreal forest cannot be explained by a difference in fire frequency, at least during the last 300 years. As climatic factors and species potential distribution did not vary significantly from south to north, we suggest that the transition from mixedwood to coniferous forests is mainly controlled by fire size and severity. Smaller and less severe fires would favor species associated with the mixedwood forests as many need survivors to reinvade burnt areas. The abundance of deciduous species in mixedwood forests, together with the presence of more lakes that can act as firebreaks, may contribute to decreases in fire size and severity. The transition between the two vegetation zones could be related to the initial setting following the vegetation invasion of the area during the Holocene. In this context, the limit of vegetation zones in systems controlled by disturbance regimes such as fires may not have reached a balance with current climatic conditions. Historical legacies and strong positive feedback between disturbance regimes and composition may filter and delay the responses to changes in climate.

Key words: boreal forest; Canada; climate change; dendroecology; disturbance regime; fire; mixedwood forest; vegetation zone.

\section{INTRODUCTION}

Forest stand distribution at the regional and landscape scales has traditionally been viewed as being driven by the direct effects of climate and landform characteristics on the growth and recruitment of tree species (Whittaker 1975). The classification of vegetation zones in Canada, as in other countries, is mainly based on these characteristics (Rowe 1972). On the other hand, we recognize disturbance regimes as one of the important factors controlling forest ecosystems (Pickett and White 1985, Engelmark et al. 1993, Frelich 2002). This is particularly true for boreal forests where

Manuscript received 15 November 2002; revised 23 September 2003; accepted 24 September 2003; final version received 20 November 2003. Corresponding Editor: S. T. Jackson.

${ }^{5}$ E-mail: bergeron.yves@uqam.ca fire (Johnson 1992, Payette 1992) and insect disturbances (MacLean 1980, Holling 1992) are widespread. In this context, it is possible that changes in forest mosaic composition may be related more closely to the effects of changes in disturbance regimes, partially driven by climate, than to a direct response to climate and landform (Overpeck et al. 1990).

Despite this recognition of the importance of natural disturbances, there are very few studies in the boreal forest that demonstrate clear relationships between disturbance regimes and the distribution of forest vegetation at the regional or landscape scales. One major exception is the work by Payette et al. (2001), who clearly showed that Quebec's forested tundra was shaped by fire disturbances and has not yet reached a steady state condition under the present climate (Payette and Gagnon 1985, Payette and Lavoie 1994). At 
a longer time scale, it has also been suggested that a change in disturbance regimes could be responsible for the changes observed in forest composition during the Holocene (Green 1982, Carcaillet et al. 2001).

There is a growing amount of literature documenting the effects of past climate changes on fire frequency in the boreal forest (Clark 1988, Bergeron 1991, Larsen and MacDonald 1998, Weir et al. 2000, Bergeron et al. 2001). In this context, there is little doubt that the current and predicted global warming will cause changes in fire regimes (Flannigan et al. 1998, 2001). Thus, it is critical to better understand how disturbance regimes affect vegetation distribution if we want to predict possible changes in forest composition due to climate change. In this paper, we address this question by using the south to north transition between the mixed and pure coniferous forests in Quebec's boreal forest.

As all major species are present in both zones, we hypothesize that the dominance of mixedwood in the south and the coniferous forest in the north is determined by a change in fire regimes. The short fire rotation, together with the large and severe fires reported for the coniferous boreal forest (Payette et al. 1989), would favor fire-adapted jack pine and black spruce (Cogbill 1985, Sirois and Payette 1989). Both species have serotinous cones and are well adapted to large crown fires occurring at relatively short intervals (Zasada et al. 1992, Greene et al. 1999). On the other hand, longer fire cycles in the southern boreal forest (Heinselman 1981, Bergeron et al. 2001), together with less severe and smaller fires would favor a succession from shade intolerant deciduous species toward shade tolerant conifers such as balsam fir, white spruce, and white cedar (Bergeron and Dubuc 1989, Frelich and Reich 1995, Bergeron 2000, Lesieur et al. 2002). A1though well adapted to regrowth after fire from root suckers and stem sprouts, aspen and paper birch may be killed by very severe fires (Greene et al. 1999). Similarly, conifers that are dependent on survivors to reinvade burnt areas would not be favored by very large and severe fires (Bergeron and Brisson 1990, Asselin et al. 2001, Kafka et al. 2001). Although this interpretation has been put forward in the literature, to our knowledge, it has never been fully supported by an independent comparative study of fire regimes.

Our objectives were to reconstruct fire regimes for a south to north transect encompassing the transition between mixed and pure coniferous boreal forests. Here, we present our results on fire regime parameters and discuss their possible effects in controlling the transition between the two vegetation zones.

\section{STUDY AREA}

The study area (from $78^{\circ} 30^{\prime}$ to $79^{\circ} 30^{\prime} \mathrm{W}$ and from $48^{\circ} 00^{\prime}$ to $50^{\circ} 00^{\prime} \mathrm{N}$ ) encompassed a territory of 15000 $\mathrm{km}^{2}$ in two ecological regions of the continuous boreal forest of Quebec (Fig. 1). The two ecological regions (the Abitibi Lowland and the Lake Matagami Lowland) are located in the western section of the boreal forest of Quebec, at the border between Quebec and Ontario (Saucier et al. 1998; Fig. 1). Ecological regions are land portions characterized by forest vegetation on mesic sites typical of the bioclimatic domain and by a particular configuration of landforms (Saucier et al. 1998). Roughly, the limit between the two ecological regions is located at $49^{\circ} 00^{\prime} \mathrm{N}$ (Fig. 1). The southern ecological region (Abitibi Lowland) belongs to the $\mathrm{Abi}$ es balsamea-Betula papyrifera bioclimatic domain and will be referred to as the mixedwood ecological region. The northern region (Lake Matagami Lowland) belongs to the Picea mariana-moss bioclimatic domain and will be referred to as the coniferous ecological region. Both ecological regions are located within the Clay Belt of Ontario and Quebec, a large physiographic unit of clay deposits left by pro-glacial Lake Ojibway (Veillette 1994). In the coniferous region, the topography is generally flat, and the most important surficial deposit is organic soil, followed by clay deposit (Robitaille and Saucier 1998). On the other hand, the mixedwood region has a more rolling topography and clay deposits are dominant, followed by organic deposits. There are more lakes, especially large lakes (>5000 ha) in the south (Fig. 1).

In general and on the regional scale, the area is influenced by cold and dry arctic air during winter, and by warm and moist air originating from the south during summer. The balance between, and the position of, these main air masses undulates over the landscape between years and throughout all seasons. This largescale climate pattern has given the boreal forest and its ecotones their positions and shaping through time (Bryson 1966, Bonan 2002). The climate of the transect is continental with cold winters and warm summers. The mean annual temperature ranges from just over $1^{\circ} \mathrm{C}$ in the southern sections of the transect to almost $0^{\circ} \mathrm{C}$ in the northern sections. A cold arctic air mass dominates the transect during winter with the mean temperature in January ranging from $-17^{\circ} \mathrm{C}$ in the south to $-20^{\circ} \mathrm{C}$ in the north. In summer, a relatively moist tropical air mass and a typically dry polar air mass take turns influencing the transect. July mean temperature ranges from $17^{\circ} \mathrm{C}$ in the south to $\sim 16^{\circ} \mathrm{C}$ in the north. Growing degree-day sums above $5^{\circ} \mathrm{C}$ are $\sim 1300-1400$ across the transect. Mean annual precipitation ranges from over $900 \mathrm{~mm}$ in the southeast to $\sim 850 \mathrm{~mm}$ in the north. Snowfall averages $\sim 300 \mathrm{~cm}$ across the transect (Environment Canada 1986a, b, 1993). Data from the Iroquois Falls meteorological station $\left(48^{\circ} 45^{\prime} \mathrm{N}, 80^{\circ} 40^{\prime} \mathrm{W}, 259 \mathrm{~m}\right.$ above sea level), located close to the center of the gradient (Fig. 1), exemplifies the local climate. The mean annual temperature is $0.8^{\circ} \mathrm{C}$, the mean of the coldest month, January, is $-17.6^{\circ} \mathrm{C}$, and the mean of the warmest month, July, is $17.1^{\circ} \mathrm{C}$. On average, the area has five months with mean temperatures $\geq 5^{\circ} \mathrm{C}$, May through September, which approximately corresponds to the length of the 

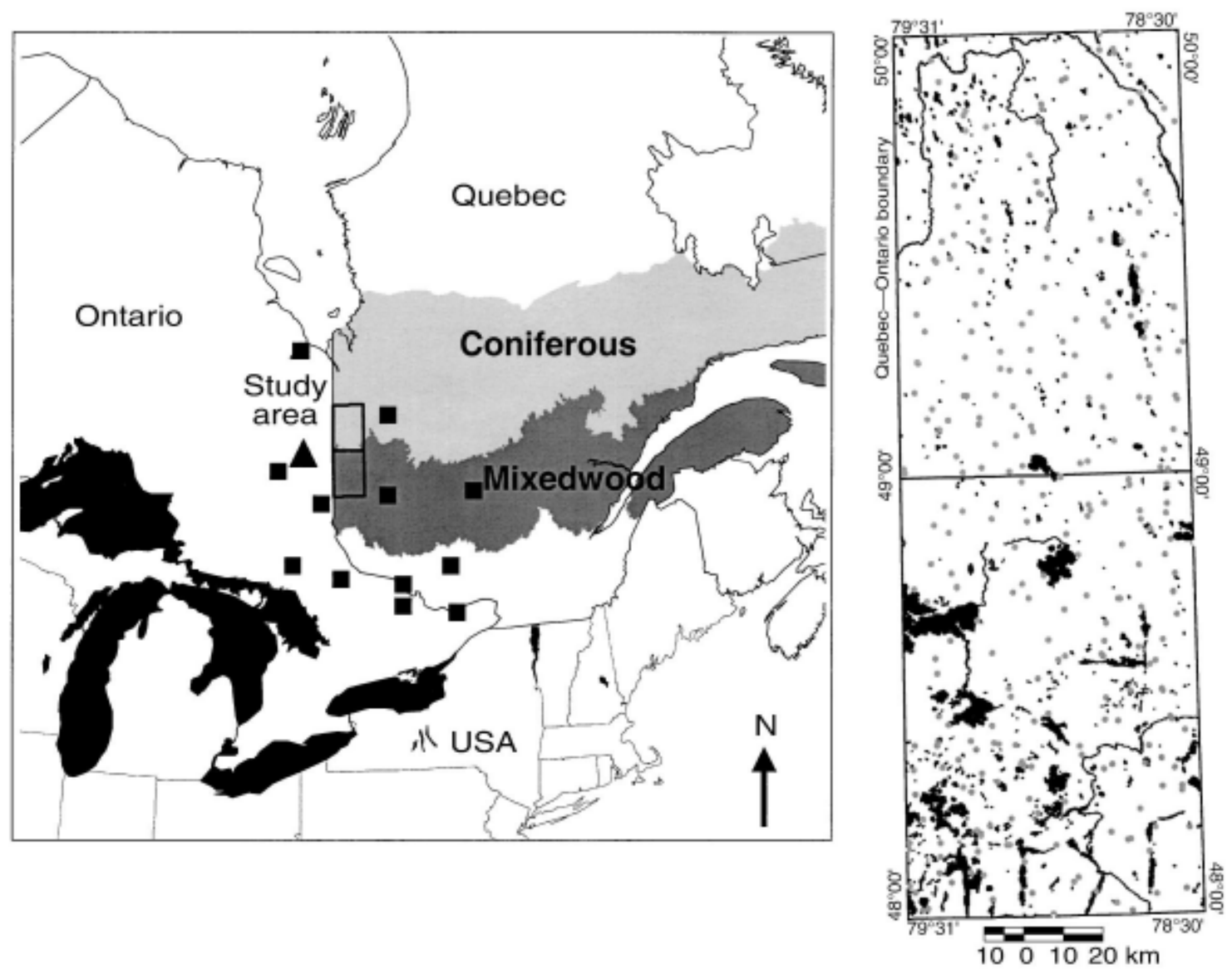

FIG. 1. Maps of the study area. The left-hand panel displays the study area with the coniferous and the mixedwood boreal domains. Squares and the triangle (Iroquois Falls station) refer to the locations of the weather stations used to characterize the climatic gradient between regions. The right-hand panel is an enlargement of the study area. The gray dots represent the sampling sites. Lakes and rivers appear in black.

growing season. Precipitation data show a maximum in July-September and a minimum in February (Environment Canada 1993).

On a longer time scale, dendroclimatic reconstruction has shown that over the last 200 years, the general climate has oscillated between a slight gradient from south to north and periods with common climate (Hofgaard et al. 1999).

The southern portion of the area was opened up in 1912 with the completion of the transcontinental railroad, and important agricultural and forestry activities began in 1916. Most of the northern portion was still composed of virgin forests until the late 1970 s, when large industrial harvesting started (Perron 1989, Vincent 1995).

\section{METHODS}

\section{Fire climate}

To determine the fire climate for the two ecological regions, we interpolated the seasonal severity rating (SSR) and meteorological variables such as tempera- ture, relative humidity, wind speed, and precipitation to the center of each region (north; $49^{\circ} 30^{\prime} \mathrm{N}, 78^{\circ} 80^{\prime}$ $\mathrm{W}$, and south; $48^{\circ} 30^{\prime} \mathrm{N}, 78^{\circ} 80^{\prime} \mathrm{W}$ ). These meteorological variables are the ones used in calculating the Canadian Forest Fire Weather Index (FWI) System (Van Wagner 1987), and the SSR is a component of the FWI System that gives a measure of potential fire control difficulty. We used data from 12 weather stations from northwestern Quebec and northeastern Ontario for the April-September period, from 1953 to 1995. We used a cubic spline procedure to interpolate the variables to the center of each region (Thiébaux and Pedder 1987, Flannigan and Wotton 1989). To characterize the potential for lightning ignitions, lightning data were obtained from the Ontario Ministry of Natural Resources (OMNR) for eight years between 1988 and 1996, excluding 1991, for which data were missing. All strikes during each of these years were summed for the north and south portions of the study area. The results were compared on a yearly basis with a paired $t$ test (Olson 1988). 


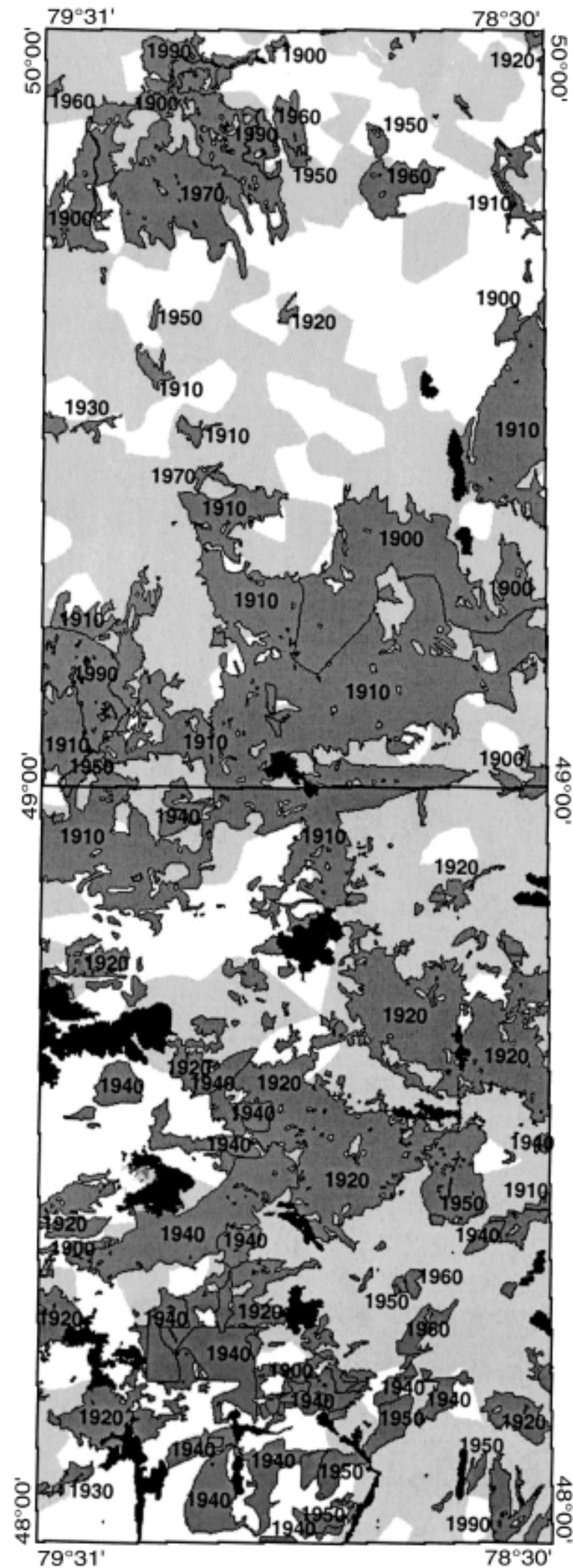

FIG. 2. Map of the time since fire. Areas that have burned since 1901 are indicated in 10-year age classes and are darkly shaded. Gray and white areas represent sectors where stand initiation occurred between 1801 and 1900 , and before 1800 , respectively.

\section{Fire history reconstruction}

In order to produce a stand initiation map (Johnson and Gutsell 1994), we reconstructed fire history using both field and archival data. Reports of individual fires are available since 1923 , and are completely mapped since 1945. Moreover, there are two types of archival data: Fires smaller than 800 ha are geo-referenced as point data, whereas the larger fires are available in polygon format. Aerial photographs (some dating from the late 1920 s and the 1930 s) made it possible to delineate boundaries.

In the case where fire extent could not be delimited using archives and aerial photographs, the date of the last fire was determined using a standard dendroecological approach (Arno and Sneck 1977, Bergeron 1991; see Methods, Dendrochronological analysis for details). Previous studies in the region (Bergeron 1991, Dansereau and Bergeron 1993, Lefort et al. 2003) had shown that the regions were characterized by having experienced a few relatively large fires $\left(>100 \mathrm{~km}^{2}\right)$. Therefore, the study area was divided into a grid of $100-\mathrm{km}^{2}$ sections where at least one site would be visited. In each site, five disks or increment cores were collected, preferably from pioneer tree species. When available, snags of jack pines and cross sections of trees bearing fire scars were also collected. In total, we sampled 315 sites (137 in the coniferous zone and 178 in the mixedwood zone) for an average of one sample per $50 \mathrm{~km}^{2}$ (Fig. 1). The sample intensity per zone was one sample $/ 57 \mathrm{~km}^{2}$ in the coniferous region vs. one sample/ $44 \mathrm{~km}^{2}$ in the mixedwood region. As jack pine snags may stand for over 100 years (Dansereau and Bergeron 1993), it was possible in some cases ( 49 and 51 sites for the coniferous and the mixedwood region, respectively) to date the time of the last fire and also the time of the previous fire, allowing us to perform an analysis of fire intervals. In each stand, the point-centered plot method was used to characterize vegetation composition (Gauthier et al. 2000). Ten points were placed at a distance of $10 \mathrm{~m}$ of each other. At each point, for the closest tree in each of the four quadrants, the species and the diameter at breast height (dbh) classes (in 5$\mathrm{cm}$ classes) were recorded. Frequency (percent) and dominance (i.e., the species with the highest importance value [relative frequency + relative basal area] in each site) were computed as the number of sites where the species were encountered or where the species was dominant, respectively. The type of surficial deposit (organic, clay, till, sand, and rock), the slope, and the drainage were also recorded (Gauthier et al. 2000).

\section{Dendrochronological analysis}

The cores and disks were first dried and then sanded mechanically using progressively finer emery paper. Living trees were aged in counting rings on disk or cores using a standard dissection microscope. For cross 
sections of dead trees, tree-ring widths were measured using a Velmex measuring system with a Unislide micrometer (Velmex Incorporated, Bloomfield, New York, USA). The cross-dating of jack pine snags was accomplished using previously developed chronologies from the same area (Dansereau and Bergeron 1993). The minimum time since fire was estimated using all available information. In most cases, it represents the age of the oldest tree sampled. In some cases, however, when we suspected that the oldest tree had survived the fire, the fire date was estimated using a cohort of trees of younger age (Bergeron 1991). Because of the lack of precision in the estimation of the real fire date, all data were presented in 10-year age classes.

\section{Fire mapping}

The fire limits obtained from the archival data or the photointerpretation of old aerial photographs were digitized and included into a GIS database. All the sample point locations were also included, together with the dendrochronological data. This allowed us to precisely map the time since fire for fires that occurred after 1900 . For older fires, because precise fire limits were not possible to identify, the map represents limits of area with similar time since fire. These areas were delimited by interpolating time since fire between each sample points using the Thiessen method (Linsley et al. 1982) in Arcview and applying a smoothing algorithm. It is generally recognized that the boreal forest fire regime is characterized by a few fires that burn large areas (Johnson et al. 1998, Weber and Stocks 1998, Stocks et al. 2002), and in this context, our map is a good estimation of fire frequency (e.g., area burned/year) or its inverse the fire cycle (time needed to burn an area equivalent to the entire territory). It does not, however, have sufficient resolution to represent the small fires and small patches of unburnt territory inside the boundaries of all large fires, but these were included whenever possible. Moreover, as the boundaries of large fires before 1880 are interpolated and because it is difficult to differentiate some of the reconstructed fires after 1880 , their exact size is not available. Consequently, fire size distributions were analyzed only with data from fires that burned between 1945 and 1998, either from archival data or aerial photographs. Similarly, as small fires can only be assessed precisely from archival data, fire occurrence (e.g., number of fires per square kilometer) was only presented for the period since 1945.

\section{Statistical ANalysis}

\section{Estimation and comparisons of fire cycles and mean age among regions}

The proportion of burnt area for each decade was derived from the time-since-fire map, and comparisons among the sectors were made using $\chi^{2}$ and Pearson $\chi^{2}$ components tests. This provided us with a time since fire (TSF) distribution. The TSF distribution can be described using a Weibull model (Johnson and Gutsell 1994):

$$
A(t)=\exp \left[-(t / b)^{c}\right]
$$

where $A(t)$ is the cumulative proportion of the landscape which survive to time $t, b$ is named the scale parameter, and $c$ is the shape parameter. The negative exponential distribution is a special case of Weibull, where $c=1$, indicating that the hazard of burning remains constant in time (Jonhson and Gutsell 1994). Under a negative exponential distribution, the cycle is equal to $b$, the mean of the distribution (Johnson and Gutsell 1994). When a cumulative TSF distribution fits a negative exponential it will appear as a straight line on semilog paper. When the parameter $c \neq 1$, it implies that the risk of burning is changing with time. When $c \neq 1$, the fire cycle is equal to $b \Gamma(1 / c+1)$.

Fire cycles were assessed using survival analysis (Proc LIFEREG, SAS Institute 1990, Johnson and Gutsell 1994, Allison 1995). This log-likelihood analysis made it possible to compare the cumulative TSF among the two regions and to estimate their fire cycles simultaneously. It also allowed us to take into account the fact that for some stands we only had a minimum time since fire (i.e., the data were censured, meaning that we know that the stand had survived for at least for a certain time). We first used the maximum likelihood technique to evaluate the variation in global fire cycle in the past. To do this, the entire TSF distribution of each region were submitted to the survival analysis under the negative exponential assumption. The same procedure was repeated sequentially, while eliminating the most recent decade. For instance, we used the entire data distribution from 1999 back to evaluate whether survival data followed a negative exponential for both regions. Then, we eliminated the areas that had burned during the decade of 1999-1990 and recomputed the cycles. The eliminated areas were considered as censured because we didn't know when they had last burned prior to 1990 . Then, we did the same procedure eliminating two, three, and four decades and so on, until we had eliminated all the decades prior 1770 . This procedure allowed us to evaluate the variation in the global fire cycle in the past and to compare the respective cycle of each region in time.

Because we had reasons to think that the fire cycle had changed either after the end of the Little Ice Age or after the first settlements in the regions, we also evaluated the fire cycles for the following periods: before $1850,1850-1920$, and after 1920. The 1850 limit between periods was selected because it corresponds to the end of the Little Ice Age in the area (Archambault and Bergeron 1992), while 1920 corresponds to the beginning of the intensive colonization of the region. In this survival analysis, the three periods were considered distinctly: $1999-1920$ with the portion of the study area that had burned before 1920 was considered 
TABLE 1. Percentage of stands where the species is present (frequency) and where the species dominates (dominance based on the highest importance value [(relative frequency + relative basal area)/2] in each stand).

\begin{tabular}{lccccc}
\hline \hline & \multicolumn{2}{c}{ Frequency (\%) } & & \multicolumn{2}{c}{ Dominance (\%) } \\
\cline { 2 - 3 } \cline { 5 - 6 } \multicolumn{1}{c}{ Species } & Mixedwood & Coniferous & & Mixedwood & Coniferous \\
\hline Abies balsamea & 51.9 & 30.6 & & 8.6 & 5.6 \\
Betula papynifera & 64.0 & 32.9 & & 13.6 & 3.8 \\
Picea glauca & 33.3 & 14.1 & & 3.9 & 0.3 \\
Picea mariana & 68.8 & 89.6 & & 24.9 & 53.4 \\
Pinus banksiana & 57.1 & 63.1 & & 32.9 & 31.0 \\
Populus tremuloides & 48.1 & 28.4 & & 14.6 & 5.3 \\
Thuja occidentalis & 5.8 & 0.0 & & 1.7 & 0.0 \\
\hline
\end{tabular}

as censured at 80 years, for the $1920-1850$ the portion of the study area that had burned after 1920 or before 1850 were censured and, similarly, for the period prior to 1850 , the portion of the study area that had burned before 1850 was considered as censured. The data for the three periods and the two sectors were included into the same analysis allowing us to assess the significance of the differences between the periods or the regions simultaneously.

Finally, to evaluate the possible influence of site types on mean stand age, we placed the map of the time since fire over a surficial geology map derived from survey of the Quebec Ministry of Natural Resources (Pelletier et al. 1996) to derive the time since fire per site type. We then compared the mean stand age for different surficial deposits using an analysis of variance (ANOVA) followed by a Student-NewmanKeuls (SNK) test for the comparison of means. Note that, in this case, the fact that some area had only minimal time since fire could not be taken into account.

\section{Fire intervals}

A fire interval distribution was constructed for each ecoregion, using only sites where two precise fire dates were available. The distributions were compared using a $\chi^{2}$ test, and the mean intervals were also computed and compared with a $t$ test.

\section{Fire direction}

All fires that have occurred since 1945 within the DCF-MRNQ database in a polygon format were used to determine the main direction of spread by fitting the longest straight line across the burnt area. For the few of the fires that had a portion of their perimeter that had burned outside the study area (in all cases, the outside area represented $<50 \%$ of the total fire area), the entire perimeter of the fire was considered in the analysis. Although it is not possible to determine whether the direction of fire spread occurred from one end to the other, the opposite way, or both, the number and total distance were compared between the northern and southern portions of the study area in four main directions (i.e., north or south, northwest or southeast, west or east, and southwest or northeast).

\section{RESULTS}

\section{Tree species distribution}

Species frequency and dominance of the main tree species are presented in Table 1 . Note that all species are present in both regions. Moreover, all species can dominate stands in both regions with the exception of Thuja occidentalis in the coniferous region.

\section{Climatic parameters}

Climatic parameters vary slightly between the south and the north (Table 2). Although not all are significantly different (Table 2), climatic parameters contribute to creating conditions more conducive to fire in the south, as shown by significant differences in the daily fire severity rating.

\section{Fire history}

The map of the time since fire is presented in Fig. 2. Large fires are observed both in the mixedwood and the coniferous regions. Proportions of the area that have not burned since 1850 and proportions that originated from fires between 1850 and 1920 are about the same in both regions (Fig. 3). However, stands originating from fires that occurred after 1920 are far more abundant in the southern portion of the area (Fig. 3).

There was slightly more lightning occurrence in the mixedwood region than in the north (Table 2). The

TABLE 2. Climatic characteristics (mean \pm 1 SE) of the southern and northern sectors for the fire season (April-September).

\begin{tabular}{|c|c|c|c|c|c|c|}
\hline Sector & Temperature $\left({ }^{\circ} \mathrm{C}\right)$ & $\begin{array}{c}\text { Relative } \\
\text { humidity }(\%)\end{array}$ & Wind $(\mathrm{m} / \mathrm{s})$ & $\begin{array}{c}\text { Seasonal } \\
\text { rainfall }(\mathrm{mm})\end{array}$ & $\begin{array}{l}\text { Daily fire } \\
\text { severity rating }\end{array}$ & $\begin{array}{c}\text { Lightning } \\
\text { occurrence } \\
\text { (no. strikes/yr) }\end{array}$ \\
\hline South & $16.17= \pm 0.92$ & $56.5^{a} \pm 2.9$ & $10.46=0.56$ & $396.93 * \pm 59.2$ & $1.09=0.38$ & $2474.5^{a} \pm 1427.2$ \\
\hline
\end{tabular}

Note: Variables with different letters are significantly different $(t$ test, $P<0.05$ ). 

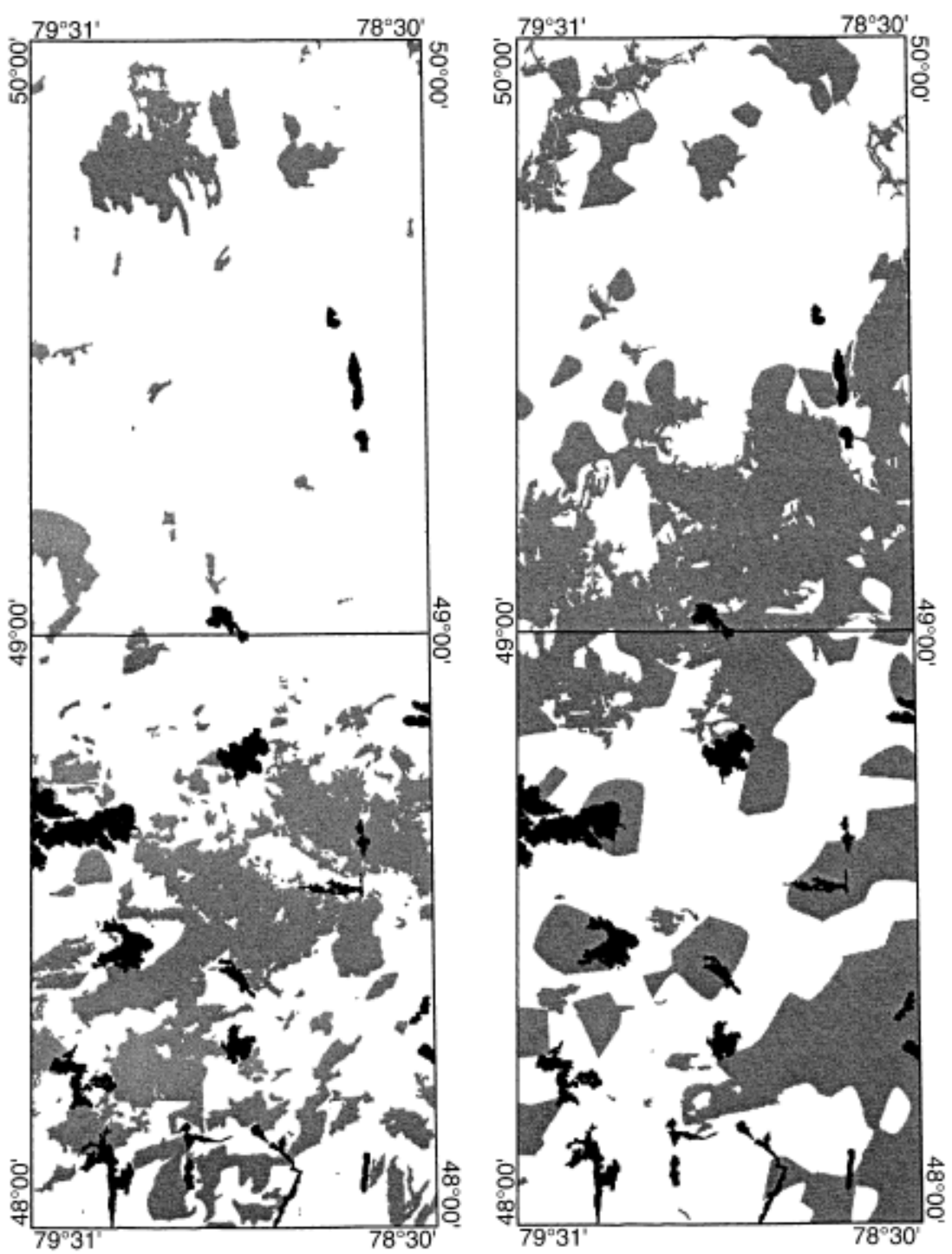

FIG. 3. Map of the study area showing areas (in gray) originating from fires that occurred (left) after 1920 and (right) between 1850 and 1920 .

comparison of the yearly number of lightning strikes between the north and south sections revealed that the difference was not significant at the $95 \%$ level. Small lightning fires ( $<800 \mathrm{ha}$ ) since 1945 were slightly more abundant in the mixedwood region than in the coniferous region (Fig. 4). Lightning fires were mainly concentrated in the northern and southern extremities of the study areas and were less abundant in the center (Fig. 4). Human-caused fires were mainly located in the mixedwood region (Fig. 4). Lightning fires occurred mainly in June and July, with a greater proportion of fires in the north in June and of fires in the south in July (Table 3).

Fire cycles

The percentage of the landscape originating from fire in each decade differed significantly $\left(\chi_{32}^{2}=66.116, P\right.$
$=0.0004)$ between the mixedwood and coniferous zones (Fig. 5a). Analysis of the Pearson components indicated that the differences between the two distributions occurred mainly after 1920. Burnt areas were globally more important in the south and occurred mainly between 1920 and 1960 , while burnt areas have been more important since 1970 in the north. Both distributions show a wide range of stand origin dates, including stands initiated before the 1700 s, with a maximum around 1910 followed by a sharp decrease since.

The complete cumulative distribution of burnt areas (Fig. 5b) shows a similar distribution for both zones. The absence of a straight line suggests, however, that fire frequency was not constant over the entire time period. The results of the sequential analysis to evaluate the temporal change in fire cycles presented in 

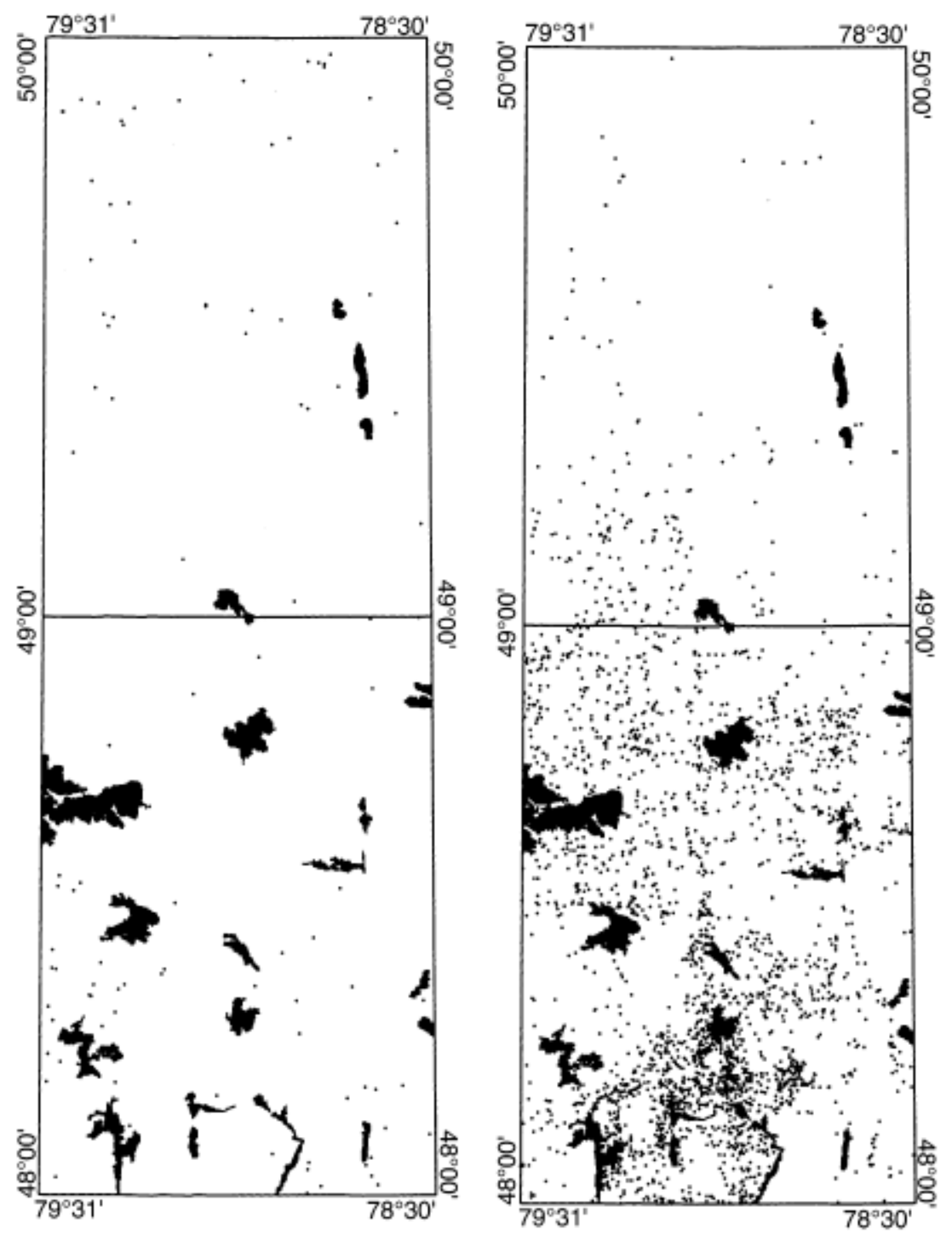

FIG. 4. Location of small fires ( $<800$ ha) caused by lightning (left) and human activities (right); data are from archives between 1945 and 1998. Numbers of fires are as follows: lightning in mixedwood, 71; coniferous, 47; human-caused in mixedwood, 2552; coniferous, 193.

Fig. 6 also revealed that the survival distributions did not follow a negative exponential but for the distributions computed for the periods that include the years prior to $1930,1920,1860,1850,1840$, and 1830 . Moreover, the cycles computed with these survival analyses

TABLE 3. Percentage of lightning fires by month between 1945 and 1998 .

\begin{tabular}{lccccccc}
\hline \hline & & \multicolumn{3}{c}{ Percentage of fires per month } \\
\cline { 3 - 7 } \multicolumn{1}{c}{ Regions } & $\begin{array}{c}\text { Total no. } \\
\text { fires }\end{array}$ & May & June & July & August & $\begin{array}{c}\text { Septem- } \\
\text { ber }\end{array}$ \\
\hline Mixedwood & 71 & 7 & 22 & 55 & 12 & 3 \\
Coniferous & 47 & 2 & 47 & 33 & 14 & 4 \\
Total & 118 & 5 & 34 & 45 & 13 & 4 \\
\hline
\end{tabular}

did not differ among the two regions; only marginally significant differences were observed for the distributions computed for the years prior to 1970, 1960, and 1950 (Wald $\chi_{1}^{2}=3.86, P=0.0494$; Wald $\chi_{1}^{2}=$ 4.5972, $P=0.0320$; Wald $\chi_{1}^{2}=4.1421, P=0.0418$, respectively).

The presence of higher area frequency in the distribution appears to coincide with periods of changes in climate (1850) or the beginning of colonization (1920) (Fig. 5a). The fire cycles computed for the periods when fire cycle changed were expected (i.e., $\sim 1920$ and $\sim 1850$; Table 4) show an increase in fire cycle length since 1850. Despite slight differences in the distribution between the south and the north, fire cycles are not significantly different (Wald $\chi_{1}^{2}=2.5937, P=$ 0.1073 ). However, there is a significant difference 


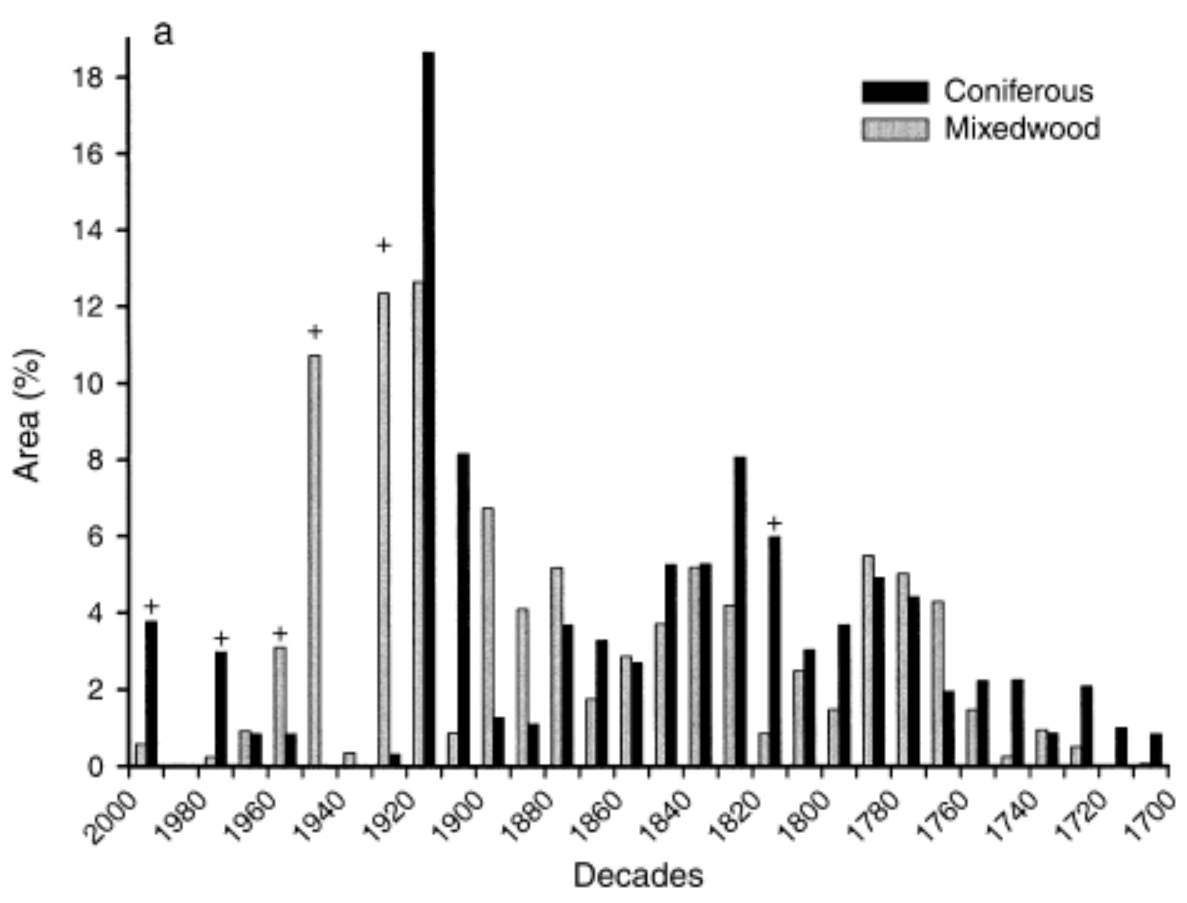

b

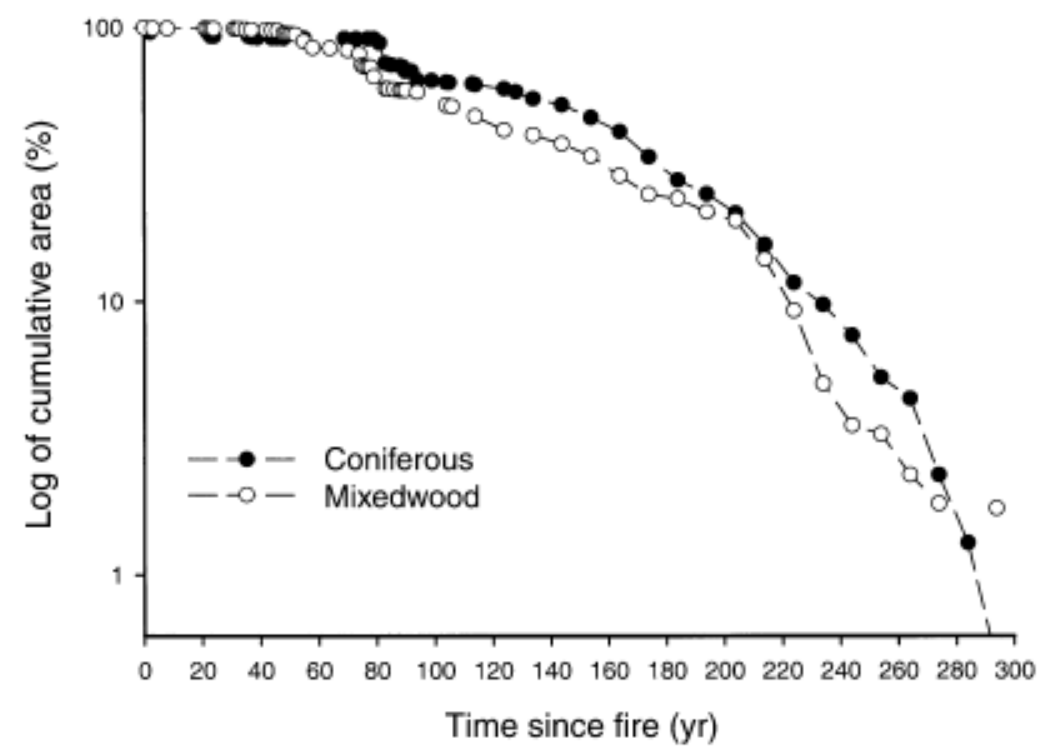

FIG. 5. (a) Distributions of time since fire for the mixedwood and coniferous regions. A " + " symbol indicates periods where the frequency (percentage of the area) is significantly different between regions. (b) Semilog cumulative time since fire for the two regions.

among the three periods (Wald $\chi_{2}^{\frac{2}{2}}=75.4827, P<$ 0.0001 ). A short fire cycle of $\sim 90$ years before 1850 increased to a fire cycle close to 124 years between 1850 and 1920 , with subsequent further increase to an estimated cycle of 360 years for the period between 1920 to the present. Overall, despite slight differences, fire cycles for each of the periods are not significantly different between the south and the north.
Average stand age varies significantly between surficial deposits (Table 5); the dry sites (sand and rock) having a lower mean age than the moist site types (unforested wetlands and organic). However, no differences or significant interactions were observed with the regions (ecoregion, $F=0.80, P=3728$; interaction among surficial deposit and ecoregion, $F=1.79, P=$ $0.1134)$. 


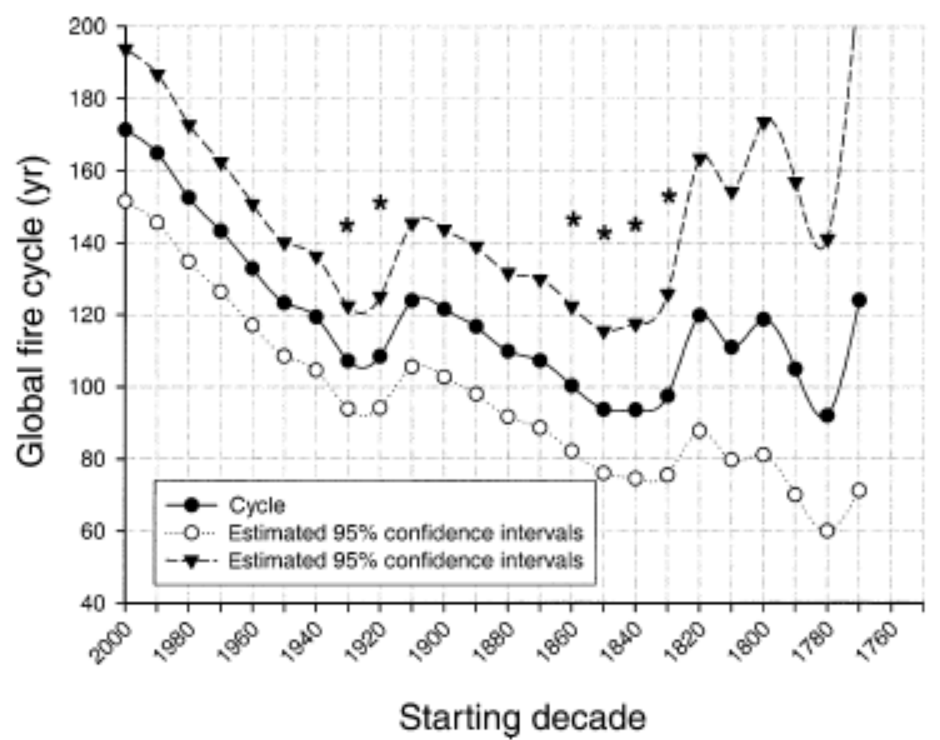

FIG. 6. Evolution of the general fire cycle through time. Computations were done sequentially by eliminating the recent decades. The stars indicate the distributions with a good fit to the negative exponential at $P>0.10$.

\section{Fire intervals}

In the study area, 100 sites (49 in the coniferous region and 51 in the mixedwood region) had snags that allowed us to precisely trace back the last two fire dates. The same number of intervals was found in the two regions, and no intervals smaller than 10 years were observed (Fig. 7). The distribution of fire intervals did not differ between the two ecoregions $\chi_{17}^{2}=17.379$, $P=0.429$ ). The mean fire interval was 90 years in the mixedwood region and 85 years in the coniferous region, and did not differ significantly $(F=0.32, P=$ 0.739).

\section{Fire size and orientation}

We identified 68 fires ( $>1 \mathrm{ha})$ in the northern sector compared to 1060 in the mixedwood since 1945 . Differences relate mainly to fires smaller than $10 \mathrm{ha}$, which are more abundant in the south, while fires between 1000 and 100000 ha are more abundant in the north (Fig. 8a). Sixty percent of the burnt area in the north was related to fires exceeding $10000 \mathrm{ha}$, whereas those very large fires were absent from the southern sector (Fig. 8b). However, there were more fires between 10 ha and 1000 ha in size in the southern region as compared to the northern one.
The analysis of the main direction of spread revealed that, since 1945, most of the distance covered by fires in the northern black spruce forest occurred in the northwest-southeast direction, although the frequency of occurrence of this direction is not high compared to the other directions. Moreover, those fires are larger, with an average distance of $14.8 \mathrm{~km}$. In the southern mixedwood region, despite the fact that fires are clearly more abundant in the southwest-northeast direction, accounting for the longest distance (Table 6), the average distance is not higher than for other directions.

\section{DISCUSSION}

\section{Temporal changes in fire cycle}

With the exception of a few decades in the early 1900 s, the observed fire cycle has constantly increased (i.e., fire frequency has decreased) during the last 300 years (Bergeron et al. 2001). Because of legacy effects, any change in fire cycle may take some times to be reflected in the TSF distribution, particularly if fire frequency is decreasing. Fire cycles respond to the $\mathrm{cu}$ mulative effects of several fires, and hence changes in the age class distribution may lag for several decades. Consequently, it is difficult to clearly identify a specific period when changes have occurred. We suggest that

TABLE 4. Fire cycle estimates (mean and confidence intervals) per region and period.

\begin{tabular}{cccc}
\hline \hline Fire cycle period & Mixedwood & Coniferous & Total \\
\hline Before 1850 & $83(65-105)$ & $101(79-129)$ & $92(75-113)$ \\
$1850-1920$ & $111(88-140)$ & $135(108-171)$ & $124(102-150)$ \\
Since 1920 & $326(250-426)$ & $398(302-527)$ & $360(281-458)$ \\
\hline
\end{tabular}

Note: Main table entries are means; numbers in parentheses are approximate $95 \%$ confidence intervals (1.96 $\times$ standard error of $b$ [ $b$ is the scale parameter]). 
TABLE 5. Comparison of the mean age (yr) of stands on the main surficial geology types in the two regions, and the area covered (\%) by each surficial geology type.

\begin{tabular}{|c|c|c|c|c|c|c|}
\hline \multirow[b]{2}{*}{ Surficial geology } & \multicolumn{2}{|c|}{ Mixedwood } & \multicolumn{2}{|c|}{ Coniferous } & \multicolumn{2}{|c|}{ Total } \\
\hline & Cover & Age & Cover & Age & Cover & Age \\
\hline Unforested wetlands & 11.6 & 128 & 35.7 & 170 & 25.0 & $162^{*}$ \\
\hline Organic & 8.6 & 140 & 10.7 & 151 & 9.8 & $147^{\text {ab }}$ \\
\hline Till & 2.4 & 120 & 14.6 & 147 & 9.2 & $144^{\text {ab }}$ \\
\hline Clay & 45.5 & 136 & 31.3 & 134 & 37.6 & $135^{\text {abs }}$ \\
\hline Rock & 26.7 & 125 & 4.8 & 96 & 14.5 & $120^{\mathrm{be}}$ \\
\hline Sand & 5.3 & 106 & 2.9 & 108 & 4.0 & $107^{e}$ \\
\hline Overall & & 130 & & 148 & & 140 \\
\hline
\end{tabular}

Note: Entries in the last column with different superscript letters are significantly different $(P<0.05)$.

the climatic change that occurred more or less abruptly $\sim 1850$ might be the principal driving factor. Since the area examined was still not settled in 1850 , the decreasing fire frequency observed probably was not caused by direct human activity. Although the influence of native people on fire frequency cannot be totally ruled out, we believe that, given the low population density in this part of the boreal forest (Côté 1993), together with knowledge of fire use by natives (Lewis 1982), human influence is insufficient to explain the observed decrease. The pattern observed during the 300 -year period is also similar to the decrease reported for the islands of Lake Duparquet (Bergeron 1991), where fires have never been suppressed. It is also consistent with others studies from eastern (Bergeron et al. 2001) and western boreal forest (Larsen 1996, Weir et al. 2000), and suggests that the phenomenon can be extended to a larger area of the boreal forests. The increase in fire cycle at Lake Duparquet was related to a reduction in the frequency of drought events since the end of the Little Ice Age (Bergeron and Archambault 1993). It has been hypothesized that the warming that started at the end of the Little Ice Age is associated with an important change in the circulation of air mass es (Hofgaard et al. 1999, Girardin et al. 2004). This

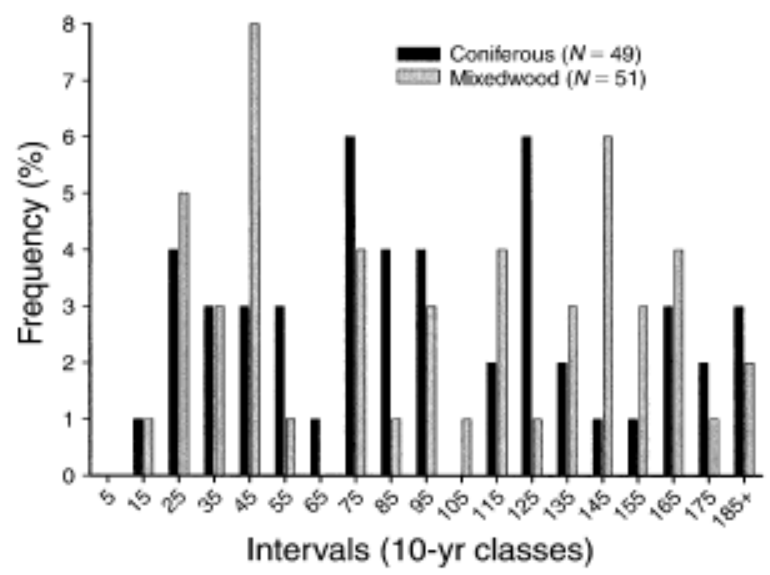

FIG. 7. Comparison of fire interval distribution in the two ecoregions. hypothesis is supported by some simulations using the Canadian General Atmospheric Circulation Model, which predicted a decrease in forest fire activity for most of the eastern boreal forest, with future warming (Flannigan et al. 1998) and the presence of possible climatic analogs during the Holocene (Flannigan et al. 2001). However, portions of the western boreal forest may be subjected to weather more conducive to fire activity (Flannigan et al. 1998). The general decrease in fire activity observed since 1850 was, however, interrupted by a period of intense fire activity during the 1910 s. In fact, $18 \%$ and $12 \%$ of the northern and southern areas, respectively, originate from fires that occurred during this decade alone (Fig. 5a).

Reconstruction of fire danger for the 20th century in the area (Lefort et al. 2003) confirms the presence of many years of extreme fire weather at the beginning of the century (1916-1924), followed by a decrease in the frequency of extreme fire seasons in the study area for the rest of the 20th century. This period also corresponds to the completion of the transcontinental railroad, whereas important agricultural and forestry activities began in 1916. The presence of the railroad, which is often a source of fire ignition, and the use of slash and burn techniques to clear lands may have exacerbated fire activity during this period (Lefort et al. 2003). Similar increases in fire activity that relate to anthropogenic impacts, although not at the same time period, are reported from various parts of the boreal forest (Lehtonen and Huttunen 1997, Weir and Johnson 1998, Niklasson and Granstrōm 2000). Intense human activities may also explain why fires remained relatively important in the southern portion of the area until the 1960 s, a period during which fire was almost absent in the virgin portion of the north. The firefighting tools available during this period seem to have been insufficient to deal effectively with large fires (Lefort et al. 2003). It is only after 1970 that the tendency seems to be reversed, as fire becomes more important in the north. Since 1960, the clearing of forest for agriculture has decreased abruptly and slash and burn techniques have been prohibited. During the same period, active fire suppression has increased. Moreover, firefighting 

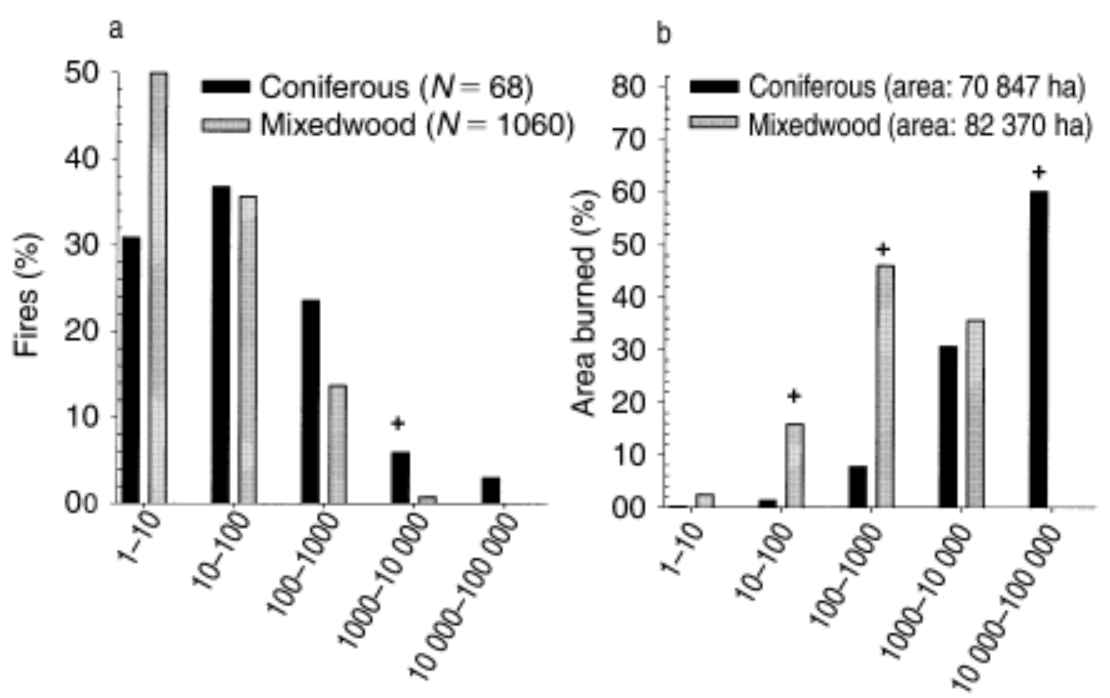

Fire size classes (ha)

FIG. 8. Fire size distribution for the mixedwood and coniferous regions: (a) percentage of events per fire size classes, and (b) percentage of the area burned by each fire size class. A " $+"$ symbol indicates classes where observed values are significantly different $(P<0.05)$ between regions.

methods have steadily improved with the 1972 introduction of water bombers, and by enhanced fire detection and initial response systems. Fire suppression was very likely more efficient in the south, which shows a greater extent of landscape fragmentation by land clearing and a well-developed road system, which increases the number of firebreaks (Foster 1983, Turner and Romme 1994) and improves firefighting capacity (Lefebvre 1972).

\section{North-south differences in climate and fire regime}

The hypothesis that historical and recent fire cycles are shorter in the coniferous forests is not supported by our study. In fact, although not significant, there is a slight inverse trend in the results. As discussed in the previous subsection, shorter fire cycles in the south could partly be explained by anthropogenic influence, but, as the trend is consistent over all periods, it also appears to be controlled by climate. Shorter fire cycles in the south are consistent with slightly higher temperature and lower precipitation observed in the south. There is no strong evidence, however, of a sharp climatic boundary between the north and the south; the transition appears mainly as a weak gradient. A similar gradient was observed by Hofgaard et al. (1999) while comparing the radial growth of black spruce and jack pine from southern to northern locations. In fact, for the last 300 years of growth, they observed periods of common response to climate or gradual changes from south to north, but they never observed sharp boundaries between the two regions. Lack of a clear correlation between vegetation composition and fire cycle, observed here spatially along a latitudinal gradient, was also reported for changes in vegetation during the Holocene (Carcaillet et al. 2001). These results support the conclusion that climate is the most important factor controlling regional fire frequency (Bessie and Johnson 1995, Hély et al. 2001) in the boreal forest.

Lightning fires are more abundant in the south (Fig. 7), consistent with the higher number of lightning events. This higher number of fires, however, is largely compensated by the size of fires in the north, which tend to be greater. In fact, although both sectors have a similar area burned per year, as suggested by the absence of significant differences in their fire cycles, the northern fire regime is characterized by fewer but

TABLE 6. The number of fires (frequency) and the distance $(\mathrm{km})$ covered by these fires in the main spread direction in the southern mixedwood and northern coniferous forests.

\begin{tabular}{|c|c|c|c|c|c|c|}
\hline \multirow[b]{2}{*}{ Direction } & \multicolumn{2}{|c|}{ Frequency } & \multicolumn{2}{|c|}{ Total distance $(\mathrm{km})$} & \multicolumn{2}{|c|}{ "Mean distance $(\mathrm{km})$} \\
\hline & $\begin{array}{l}\text { Mixed- } \\
\text { wood }\end{array}$ & $\begin{array}{l}\text { Conifer- } \\
\text { ous }\end{array}$ & $\begin{array}{l}\text { Mixed- } \\
\text { wood }\end{array}$ & $\begin{array}{l}\text { Conifer- } \\
\text { ous }\end{array}$ & $\begin{array}{c}\text { Mixed- } \\
\text { wood }\end{array}$ & $\begin{array}{c}\text { Conifer- } \\
\text { ous }\end{array}$ \\
\hline $\begin{array}{l}\text { North-south } \\
\text { Northwest-southeast } \\
\text { West-east } \\
\text { Southwest-northeast }\end{array}$ & $\begin{array}{r}11 \\
7 \\
9 \\
34\end{array}$ & $\begin{array}{l}6 \\
5 \\
0 \\
5\end{array}$ & $\begin{array}{r}40.3 \\
16.4 \\
28.4 \\
151.0\end{array}$ & $\begin{array}{c}43.6 \\
73.7 \\
0 \\
26.3\end{array}$ & $\begin{array}{l}3.66 \\
2.34 \\
3.15 \\
4.44\end{array}$ & $\begin{array}{c}7.27 \\
14.74 \\
0 \\
5.26\end{array}$ \\
\hline
\end{tabular}


larger fires. Many factors can explain why fires tend to be larger in the north. First, the flat topography (Robitaille and Saucier 1998) of the north and the lack of large lakes (Fig. 1) that can act as firebreaks (Larsen 1997) may enhance fire spread. Moreover, other studies (Cyr 2001) showed that the extensive bogs abundant in the north did not act as efficient firebreaks. Second, the dominance of conifers can also favor fire spread (Van Wagner 1983). Using simulations with the Canadian Fire Behavior Prediction (FBP) System (Forestry Canada Fire Danger Group 1992), Hély et al. $(2000,2001)$ showed that the rate of spread and final size of fires increase under similar weather conditions when fires spread through conifer stands instead of mixedwood or hardwood boreal stands. The occurrence of many northern fires in June (most fires occur in July in the south) when understory vegetation is not fully developed may also contribute to the presence of larger fires (Hély et al. 2001).

Dominant NW wind direction in the north (SW in the south) may also enhance fire spread. In fact, it has been suggested that fires are associated with the passage of a cold front (Brotak and Reifsnyder 1977). The passage of a cold front is also associated with a shift in wind direction, from the southwest to the northwest. This might be very important to explain the size of those fires, as the flank of a southwest fire would become the head of the fire as the wind shifts, resulting in a rapid and significant growth of the fire (Flannigan and Wotton 2001). Our results are congruent with these propositions.

Large fires ( $>10000 \mathrm{ha})$ are generally more intense than smaller fires (Turner et al. 1994, Eberhart and Woodard 1987) and may thus be responsible for higher mortality in the burnt area (Kafka et al. 2001). Empirical results from 16 recent fires that occurred in 1995 and 1996 in northwestern Quebec (Bergeron et al. 2002) showed a good relationship between the size of the fires and the proportion of the area where tree mortality was high. According to this observation, we can suggest that the southern sector is characterized by fires of lower impact with a larger proportion of survivors, at least immediately after the fire.

\section{Consequences on the mixedwood-coniferous transition}

From our results, we can conclude that the mixedwood-coniferous transition in northwestern Quebec is not directly controlled by a dramatic change in fire frequency. Because all the mixedwood species (aspen, birch, balsam fir, and white spruce) are present and can reproduce locally in abundance (Gauthier et al. 2000) in the black spruce- and jack pine-dominated forest, a physiological limit directly controlled by climate is also excluded.

Among mixedwood species, many would be disadvantaged by large fires because they have to reseed from protected trees. Many studies have shown an ex- ponential decrease of seedling abundance at the fire margin (Galipeau et al. 1997, Greene et al. 1999, Asselin et al. 2001). In a large fire (50000 ha), Kafka et al. (2001) found that only $12.5 \%$ of the burnt area was located $<200 \mathrm{~m}$ away from unburnt islands or fire margins. Thus, remaining patches of scattered green trees may be important for maintaining the presence of species that rely on the presence of survivors in the landscape.

Large fires are generally more intense and thus have a greater impact on tree mortality. Intensity is also higher in pure coniferous stands than in mixedwood and hardwood stands (Hély et al. 2003). Both of theses factors lead to a reduction in the number of green trees inside the fire perimeter and thus limit the capability of survivor-dependant species to efficiently reinvade burnt areas. This might be dramatic for conifers such as balsam fir and white cedar, which have a low dispersal potential, and, to a lesser extent, for white spruce. The ability of aspen and birch to disperse over long distances allows them to better cope with large fires. Aspen can also reproduce from root suckers, while birch may resprout from the stem collar or germinate from a seed bank. In these later cases, however, very intense fires associated with an important duff removal may in some cases kill the root systems and the seed banks (Zasada et al. 1992). Besides the depth of burn, which will determine whether white birch and trembling aspen will be able to resprout from unburned roots (Lavertu et al. 1994), it is the distance from survivors that will affect the regeneration of those species.

Other factors may interact with fire regimes to set the limit between mixedwood and coniferous forests in northwestern Quebec. Decreasing abundance toward the north of upland sites, which are highly favorable to the growth of mixedwood (Carleton and Maycock 1978, Gauthier et al. 2000), are also decreasing the availability of seed trees at the landscape level. A lower seed production due to climatic stress may also affect the dispersal potential of certain species (Tremblay et al. 2002). Decreasing abundance of lakes, which constitute firebreaks (Larsen 1997), is also a factor contributing to the decrease of survivors. This in particular might explain why species such as white pine and red pine, which are strongly associated with islands and lake margins, attain their northern limit in the mixedwood region (Bergeron and Brisson 1990) despite potentially being able to regenerate successfully further north (Flannigan and Bergeron 1998, Engelmark et al. 2000 ). Although white cedar is still present in very low abundance in the north, the same phenomenon may limit its distribution, which is strongly associated with lake margins protected from fires (Heinselman 1973, Denneler et al. 1999).

\section{Stability of the vegetation zones}

The mixedwood-coniferous margin in northwestern Quebec does not appear to respond directly to the ef- 
fects of climate on regeneration or to the indirect effects of climate through changes in fire frequency, but to a complex interaction between fire size and severity and the potential of the species to survive fires and disperse into the burnt areas. There is no clear evidence that the observed differences in fire behavior could be attributed only to a difference of climate between the two regions. There are, however, strong positive interactions between the present vegetation types and the characteristics of the fire regimes. The presence of strong deciduous components in mixedwood contributes to the presence of smaller fires of lower intensity, making it possible to maintain mixedwood-associated species. On the other hand, large tracts of coniferous forest may favor larger fires of higher intensity, which in turn favor tree species with aerial seed banks. In this context, the settings of the transition may relate more to the longterm Holocene history that set the initial composition than to the present or recent past climate. In fact, local reconstruction of vegetation using pollen analysis (Carcaillet et al. 2001) suggests that the transition between the mixedwood and coniferous zones was set immediately after the deglaciation. It is hypothesized that the mixedwood invasion at the southern margin of Lake Ojibway-Barlow from the south met, at the drainage of the lake 8000 years ago, the coniferous forest dominated by black spruce and jack pine that came from the recently deglaciated areas around the lake. There were, however, regional changes in the abundance of certain species during the Holocene. White cedar and white pine decreased in abundance, while jack pine and black spruce increased (Richard 1980). These changes are partly connected with an important increase in fire frequency starting about 2500 years ago (Carcaillet et al. 2001). The presence of large tracts of black spruce and jack pine stands well south of the actual mixedwood-coniferous limit is possibly explained by extreme fire events that have occurred during this period.

A warmer climate and possibly a decreasing abundance of fires due both to climate changes and fire suppression (Bergeron et al. 2000, Flannigan et al. 1998) may contribute in favoring an extension of the mixedwood into the coniferous forests. This phenomenon may be limited, however, by the presence in coniferous forests of a thick mat of organic matter and mosses (Boudreault et al. 2002) not suitable for the regeneration of mixedwood species, particularly the hardwoods. Industrial logging activities that contribute to decreases in organic matter and make mineral soils accessible may accelerate this transition (Carleton and MacLellan 1994, Nguyen-Xuan et al. 2000, Reich et al. 2001). It has been suggested that the important increase in hardwood species observed in the southern boreal forests since the colonization is due to a combination of logging followed by human-caused fires, a process that eliminates conifer seed trees and favors hardwood invasion (Lefort et al. 2003).

\section{CONCLUSION}

Limits of vegetation zones in systems controlled by disturbance regimes such as fires may not have reached a balance with current climatic conditions. Historical legacies and strong positive feedback between disturbance regimes and composition filter and delay the responses to changes in climate. As the present situation has not reached a balance in northwestern Quebec, it cannot be used as such in models of future vegetation patterns and species distributions. It is thus essential to better document the complex interactions between disturbance regimes and their specific controls over the entire forest mosaics if we want to model possible effects of climate changes. In controlling disturbances and thus ecological processes, humans can have a profound effect on the future of forests (Haeussler et al. 2002).

\section{ACKNOWLEDGMENTS}

Financial support was provided by the Natural Sciences and Engineering Research Council of Canada (Network of Centres of Excellence in Sustainable Forest Management Program), by Quebec's Ministry of Science and Technology, the Federal Government Green Plan program, and Tembec and Norbord Forest Industries. We thank France Conciatori, who did a large part of the fieldwork. We also thank Mike Apps, Stephen T. Jackson, and an anonymous reviewer for comments that have greatly improve the manuscript.

\section{Literature Cited}

Allison, P. D. 1995. Survival analysis using the SAS system: a practical guide. SAS Institute, Cary, North Carolina, USA.

Archambault, S., and Y. Bergeron. 1992. An 802-year treering chronology from the Quebec boreal forest. Canadian Journal of Forest Research 22:674-682.

Arno, S. F., and K. M. Sneck. 1977. A method for determining fire history in coniferous forests of the mountain west. General Technical Report INT-42, USDA Forest Service, Ogden, Utah, USA.

Asselin, H., M.-J. Fortin, and Y. Bergeron. 2001. Spatial distribution of late-successional coniferous species regeneration following disturbance in southwestern Québec boreal forest. Forest Ecology and Management 140:29-37.

Bergeron, Y. 1991. The influence of island and mainland lakeshore landscapes on boreal forest fire regimes. Ecology 72:1980-1992.

Bergeron, Y. 2000. Species and stand dynamics in the mixed woods of Quebec's southern boreal forest. Ecology 81: 1500-1516.

Bergeron, Y., and S. Archambault. 1993. Decreasing frequency of forest fires in the southern boreal zone of Québec and its relation to global warming since the end of the "Little Ice Age." Holocene 3:255-259.

Bergeron, Y., and J. Brisson. 1990. Fire regime in red pine stands at the northern limit of the species' range. Ecology 71:1352-1364.

Bergeron, Y., and M. Dubuc. 1989. Succession in the southern part of the Canadian boreal forest. Vegetatio 79:51-63.

Bergeron, Y., S. Gauthier, V. Kafka, P. Lefort, and D. Lesieur. 2001. Natural fire frequency for the eastern Canadian Boreal forest: consequences for sustainable forestry. Canadian Journal of Forestry Research 31:384-391.

Bergeron, Y., A. Leduc, B. D. Harvey, and S. Gauthier. 2002. Natural fire regime: a guide for sustainable management of the Canadian boreal forest. Silva Fennica 36:81-95. 
Bessie, W. C., and E. A. Johnson. 1995. The relative importance of fuels and weather on fire behavior in subalpine forests. Ecology 76:747-762.

Bonan, G. B. 2002. Ecological climatology: concepts and applications. Cambridge University Press, Cambridge, UK.

Boudreault, C., Y. Bergeron, S. Gauthier, and P. Drapeau. 2002. Bryophyte and lichen communities in mature to oldgrowth stands in eastern boreal forests of Canada. Canadian Journal of Forest Research 32:1080-1093.

Brotak, E., W. E. Reifsnyder. 1977. An investigation of the synoptic situation associated with major wildland fires. Journal of Applied Meteorology 16:867-870.

Bryson, R. A. 1966. Air masses, stream lines, and the boreal forest. Geographical Bulletin 8:228-269.

Carcaillet, C., Y. Bergeron, P. J. H. Richard, B. Fréchette, S. Gauthier, and Y. T. Prairie. 2001. Change of fire frequency in the eastern Canadian boreal forests during the Holocene: does vegetation composition or climate trigger the fire regime? Journal of Ecology 89:930-946.

Carleton, T. J., and P. MacLellan. 1994. Woody vegetation responses to fire versus clear-cutting logging: a comparative survey in the central Canadian boreal forest. Écoscience 1:141-152.

Carleton, T. J., and P. F. Maycock. 1978. Dynamics of the boreal forest south of James Bay. Canadian Journal of Botany 56:1157-1173.

Clark, J. S. 1988. Effect of climate change on fire regimes in northwestern Minnesota. Nature 334:33-235.

Cogbill, C. V. 1985. Dynamics of the boreal forests of the Laurentian Highlands, Canada. Canadian Journal of Forest Research 15:252-261.

Côté, M. 1993. Préhistoire de l'Abitibi-Témiscamingue. Recherches amérindiennes au Québec 23:5-24.

Cyr, D. 2001. La place des forêts anciennes du Nord de l'Abitibi dans une mosaïque régulée par les incendies forestiers. Thesis. Université du Québec à Montréal, Montreal, Quebec, Canada.

Dansereau, P.-R., and Y. Bergeron. 1993. Fire history in the southern boreal forest of northwestern Quebec. Canadian Journal of Forest Research 23:25-32.

Denneler, B., Y. Bergeron, and Y. Bégin. 1999. An attempt to explain the distribution of the tree species composing the riparian forests of Lake Duparquet, southern boreal region of Quebec, Canada. Canadian Journal of Botany 77: $1744-1755$.

Eberhart, K. E., and P. M. Woodard. 1987. Distribution of residual vegetation associated with large fires in Alberta. Canadian Journal of Forest Research 17:1207-1212.

Engelmark, O., Y. Bergeron, and M. D. Flannigan. 2000. Age structure of Eastern White Pine, Pinus stobus L., at its northern distribution limit in Québec. The Canadian Field Naturalist 114:601-604.

Engelmark, O., R. H. W. Bradshaw, and Y. Bergeron. 1993. Disturbance dynamics in boreal forest: introduction. Journal of Vegetation Science 4:729-732.

Environment Canada. 1986a. Climatic atlas Canada: map series number 1. Temperature and growing degree days. Atmospheric Environment Service, Environment Canada, Ottawa, Ontario, Canada.

Environment Canada. 1986b. Climatic atlas Canada: map series number 2. Precipitation. Atmospheric Environment Service, Environment Canada, Ottawa, Ontario, Canada.

Environment Canada. 1993. Canadian climate normals 1961-1990. Atmospheric Environment Service, Environment Canada, Ottawa, Ontario, Canada.

Flannigan, M. D., and Y. Bergeron. 1998. Possible role of disturbance in shaping the northern distribution of Pinus resinosa. Journal of Vegetation Science 9:477-482.

Flannigan, M. D., Y. Bergeron, O. Engelmark, and B. M. Wotton. 1998. Future wildfire in the circumboreal forests in relation to global warming. Journal of Vegetation Science 9:469-476.

Flannigan, M. D., I. Campbell, M. Wotton, C. Carcaillet, P. Richard, and Y. Bergeron. 2001. Future fire in Canada's boreal forest: paleoecology results and general circulation model-regionalclimate model simulations. Canadian Journal of Forest Research 31:854-864.

Flannigan, M. D., and B. M. Wotton. 1989. A study of interpolation methods for forest fire danger rating in Canada. Canadian Journal of Forest Research 19:1059-1066.

Flannigan, M. D., and B. M. Wotton. 2001. Climate, weather and area burned. Pages 335-357 in E. A. Johnson and K. Miyanishi, editors. Forest fires: behavior and ecological effects. Academic Press, New York, New York, USA.

Forestry Canada Fire Danger Group. 1992. Development and structure of the Canadian forest fire behavior system. Information Report ST-X-3, Forestry Canada, Science and Sustainable Direction, Ottawa, Ontario, Canada.

Foster, D. R. 1983. The history and pattern of fire in the boreal forest of southeastern Labrador. Canadian Journal of Botany 61:2459-2471.

Frelich, L. E. 2002. Forest dynamics and disturbance regimes: studies from temperate evergreen-deciduous forests. Cambridge University Press, New York, New York, USA.

Frelich, L. E., and P. B. Reich. 1995. Spatial patterns and succession in a Minnesota southern-boreal forest. Ecological Monographs 65:325-346.

Galipeau, C., D. Kneeshaw, and Y. Bergeron. 1997. White spruce and balsam fir colonization of a site in the southeastern boreal forest as observed 68 years after fire. Canadian Journal of Forest Research 27:139-147.

Gauthier, S., L. De Grandpré, and Y. Bergeron. 2000. Differences in forest composition in two boreal forest ecoregions of Quebec. Journal of Vegetation Science 11:781790.

Girardin, M. P., J. Tardif, M. D. Flannigan, B. M. Wotton, and Y. Bergeron. 2004. Trends and periodicities in the Canadian Drought Code and their relationships with atmospheric circulation for the southern Canadian boreal forest. Canadian Journal of Forest Research 34:103-119.

Green, D. G. 1982. Fire and stability in the postglacial forests of southwest Nova Scotia. Journal of Biogeography 9:2940 .

Greene, D. F., J. C. Zasada, L. Sirois, D. Kneeshaw, H. Morin, I. Charron, and M.-J. Simard. 1999. A review of the regeneration dynamics of North American boreal forest tree species. Canadian Journal of Forest Research 29:824-839.

Haeussler, S., L. Bedford, A. Leduc, Y. Bergeron, and J. M. Kranabetter. 2002. Silvicultural disturbance severity and plant communities of the southern Canadian boreal forest. Silva Fennica 36:307-327.

Heinselman, M. L. 1973. Fire in the virgin forests of the Boundary Waters Canoe Area, Minnesota. Quaternary Research 3:329-382.

Heinselman, M. L. 1981. Fire and succession in the conifer forests of North America. Pages 374-405 in D. C. West, H. H. Shugart, and D. B. Botkin, editors. Forest succession: concepts and application. Springer-Verlag, New York, New York, USA.

Hély, C., Y. Bergeron, and M. D. Flannigan. 2000. Effects of stand composition on fire hazard in the mixed-wood Canadian boreal forest. Journal of Vegetation Science 11: $813-824$

Hély, C., Y. Bergeron, and M. D. Flannigan. 2003. Modeling tree mortality following wildfire in the southeastern $\mathrm{Ca}$ nadian mixed-wood boreal forest. Forest Science 49:566576.

Hély, C., M. Flannigan, Y. Bergeron, and D. McRae. 2001. Role of vegetation and weather on fire behavior in the 
Canadian mixed-wood boreal forest using two fire behavior prediction systems. Canadian Journal of Forest Research 31:430-441.

Hofgaard, A., J. Tardif, and Y. Bergeron. 1999. Dendroclimatic response of Picea mariana and Pinus banksiana along a latitudinal gradient in eastern Canadian boreal forest. Canadian Journal of Forest Research 29:1333-1346.

Holling, C. S. 1992. The role of forest insects in structuring the boreal landscape. Pages 170-191 in H. H. Shugart, R. Leemans, and G. B. Bonan, editors. A systems analysis of the global boreal forest. Cambridge University Press, Cambridge, UK.

Johnson, E. A. 1992. Fire and vegetation dynamics-studies from the North American boreal forest. Cambridge University Press, Cambridge, UK.

Johnson, E. A., and S. L. Gutsell. 1994. Fire frequency models, methods and interpretations. Advances in Ecological Research 25:239-287.

Johnson, E. A., K. Miyanishi, and J. M. H. Weir. 1998. Wildfires in the western Canadian boreal forest: landscape patterns and ecosystem management. Journal of Vegetation Science 9:603-610.

Kafka, V., S. Gauthier, and Y. Bergeron. 2001. Fire impacts and crowning in the boreal forest: study of a large wildfire in western Quebec. International Journal of Wildland Fire 10:119-127.

Larsen, C. P. S. 1996. Fire and climate dynamics in the boreal forest of northern Alberta, Canada, from AD 1850 to 1989. Holocene 6:449-456.

Larsen, C. P. S. 1997. Spatial and temporal variations in boreal forest fire frequency in northern Alberta. Journal of Biogeography 24:663-673.

Larsen, C. P. S., and G. M. MacDonald. 1998. An 840-year record of fire and vegetation in a boreal white spruce forest. Ecology 79:106-118.

Lavertu, D., Y. Mauffette, and Y. Bergeron. 1994. Suckering success of aspen (Populus tremuloides Michx.) in relation to stand age and soil disturbance. Journal of Vegetation Science 5:561-568.

Lefebvre, P. 1972. Manuel de lutte contre les feux de forêt. Éditeur officiel du Québec, Quebec City, Quebec, Canada.

Lefort, P., S. Gauthier, and Y. Bergeron. 2003. The influence of fire weather and land use on the fire activity of the Lake Abitibi area, eastern Canada. Forest Science 49:509-521.

Lehtonen, H., and P. Huttunen. 1997. History of forest fires in eastern Finland from the fifteenth century AD: the possible effects of slash-and-burn cultivation. Holocene 7: 223-228.

Lesieur, D., S. Gauthier, and Y. Bergeron. 2002. Fire frequency and vegetation dynamics for the south central boreal forest of Quebec, Canada. Canadian Journal of Fores Research 32:1996-2009.

Lewis, H. T. 1982. A time of burning. Occasional Publication Number 17. Boreal Institute for Northern Studies, University of Alberta, Edmonton, Alberta, Canada.

Linsley, R. K., M. A. Kohler, and J. L. Paulhus. 1982. Hydrology for engineers. Third edition. McGraw-Hill, New York, New York, USA.

MacLean, D. A. 1980. Vulnerability of fir-spruce stands during uncontrolled spruce budworm outbreaks: a review and discussion. Forestry Chronicle 56:213-221.

Nguyen-Xuan, T., Y. Bergeron, D. Simard, J. W. Fyles, and D. Paré. 2000. The importance of forest floor disturbance in the early regeneration patterns of the boreal forest of western and central Quebec: a wildfire versus logging comparison. Canadian Journal of Forest Research 30:13531364.

Niklasson, M., and A. Granström. 2000. Numbers and sizes of fires: long-term spatially explicit fire history in a Swedish boreal landscape. Ecology 81:1484-1499.
Olson, C. L. 1988. Making sense of data. William C. Brown Publishers, Dubuque, Iowa, USA.

Overpeck, J. T., D. Rind, and R. Goldberg. 1990. Climateinduced changes in forest disturbance and vegetation. Nature 343:51-53.

Payette, S. 1992. Fire as a controlling process in the North American boreal forest. Pages 144-169 in H. H. Shugart, R. Leemans, and G. B. Bonan, editors. A systems analysis of the global boreal forest. Cambridge University Press, Cambridge, UK.

Payette, S., M. J. Fortin, and I. Gamache. 2001. The subarctic forest-tundra: the structure of a biome in a changing climate. Bioscience 51:709-718.

Payette, S., and R. Gagnon. 1985. Late Holocene deforestation and tree regeneration in the forest-tundra of Québec. Nature 313:570-572.

Payette, S., and C. Lavoie. 1994. The arctic tree line as a record of past and recent climatic changes. Environmental Reviews 2:78-90.

Payette, S., C. Morneau, L. Sirois, and M. Desponts. 1989. Recent fire history of the northern Québec biomes. Ecology 70:656-673.

Pelletier, G., Y. Dumont, M. Bédard, and J. Bergeron. 1996. SIFORT, un système hybride des modes vectoriel et matriciel pour une nouvelle approche de l'analyse forestière. Arpenteur-Géomètre 23:8-9.

Perron, M. 1989. L'exploitation forestière dans la région de La Sarre en Abitibi: 1910-1980. Capitale forestière du Canada, La Sarre, Québec, Canada.

Pickett, S. T. A., and P. S. White. 1985. The ecology of natural disturbance and patch dynamics. Academic Press, New York, New York, USA.

Reich, P. B., P. Bakken, D. Carlson, L. E. Frelich, S. K. Friedman, and D. F. Grigal. 2001. Influence of logging, fire, and forest type on biodiversity and productivity in southern boreal forests. Ecology 82:2731-2748.

Richard, P. J. H. 1980. Histoire postglaciaire de la végétation au sud du lac Abitibi, Ontario et Québec. Géographie physique et Quaternaire 34:77-94.

Robitaille, A., and J.-P. Saucier. 1998. Paysages régionaux du Québec méridional. Les Publications du Québec, SainteFoy, Quebec, Canada.

Rowe, J. S. 1972. Forest regions of Canada. Canadian Forest Service Publication Number 1300, Environment Canada, Ottawa, Ontario, Canada.

SAS Institute. 1990. SAS/STAT user's guide. Version 6. Fourth edition. SAS Institute, Cary, North Carolina, USA.

Saucier, J.-P., J.-F. Bergeron, P. Grondin, and A. Robitaille. 1998. Les regions écologiques du Québec méridional. Third version. L'Aubelle 124:S1-S12.

Sirois, L., and S. Payette. 1989. Postfire black spruce establishment in subarctic and boreal Quebec. Canadian Journal of Forest Research 19:1571-1580.

Stocks, B. J., J. A. Mason, J. B. Todd, E. M. Bosch, B. M. Wotton, B. D. Amiro, M. D. Flannigan, K. G. Hirsch, K. A. Logan, D. L. Martell, and W. R. Skinner. 2002. Large forest fires in Canada, 1959-1997. Journal of Geophysical Research 107:8149.

Thiébaux, H. J., and M. A. Pedder. 1987. Spatial objective analysis: with applications in atmospheric science. Academic Press, London, UK.

Tremblay, M. F., Y. Bergeron, D. Lalonde, and Y. Mauffette. 2002. The potential effects of sexual reproduction and seedling recruitment on the maintenance of red maple (Acer rubrum L.) populations at the northern limit of the species range. Journal of Biogeography 29:365-373.

Turner, M. G., W. W. Hargrove, R. H. Gardner, and W. H. Romme. 1994. Effects of fire on landscape heterogeneity in Yellowstone National Park, Wyoming. Journal of Vegetation Science 5:731-742. 
Turner, M. G., and W. H. Romme. 1994. Landscape dynamics in crown fire ecosystems. Landscape Ecology 9:59-77.

Van Wagner, C. E. 1983. Fire behaviour in northern conifer forests and shrublands. Pages 65-80 in R. W. Wein and D. A. MacLean, editors. The role of fire in northern circumpolar ecosystems. John Wiley and Sons, New York, New York, USA.

Van Wagner, C. E. 1987. Development and structure of the Canadian Forest Fire Weather Index System. Forestry Technical Report 35, Canadian Forest Service, Ottawa, Ontario, Canada.

Veillette, J. J. 1994. Evolution and paleohydrology of glacial lakes Barlow and Ojibway. Quaternary Science Review 13: 945-971.

Vincent, O. 1995. Histoire de l'Abitibi-Témiscamingue. Institut québécois de recherche sur la culture, Quebec City, Quebec, Canada.
Weber, M. G., and B. J. Stocks. 1998. Forest fires and sustainability in the boreal forests of Canada. Ambio 27:545550 .

Weir, J. M. H., and E. A. Johnson. 1998. Effects of escaped settlement fires and logging on forest composition in the mixed-wood boreal forest. Canadian Journal of Forest Research 28:459-467.

Weir, J. M. H., E. A. Johnson, and K. Myanishi. 2000. Fire frequency and spatial age mosaic of the mixed wood boreal forest in western Canada. Ecological Applications 10: 1162-1177.

Whittaker, R. H. 1975. Communities and ecosystems. Macmillan, New York, New York, USA.

Zasada, J., T. L. Sharik, and M. Nygren. 1992. The reproductive process in boreal forest trees. Pages 85-125 in $\mathrm{H}$. H. Shugart, R. Leemans, and G. B. Bonan, editors. A systems analysis of the global boreal forest. Cambridge University Press, Cambridge, UK. 